\title{
POSTMEMORIAL EXPERIENCES - COMPARING AUSTRALIAN AND CANADIAN SECOND GENERATION MIGRANT POETRY ON THE BASIS OF SELECTED POETRY BY LILY BRETT AND ANNE MICHAELS ${ }^{*}$
}

\author{
Dagmara DREWNIAK (Adam Mickiewicz University in Poznań) \\ ORCID: 0000-0003-0981-2331
}

\section{Speaking the Unspeakable}

In the discussion of postmemory, understood primarily as the legacy the second generation Holocaust survivors inherit from their parents and other ancestors, one of the most important experiences is being "dominated by narratives that preceded their birth, whose own belated stories are evacuated by the stories of the previous generation shaped by traumatic events that can be neither understood or recreated." Many scholars have tackled the issue and located the phenomenon of postmemorial expression within memory and trauma studies as well as in the context of forced emigration. Additionally, such art frequently touches upon constructing the self within the transcultural and transnational paradigm. As a result, while considering the fusion of poetry and the Holocaust, Adorno's famous statement that "To write poetry after Auschwitz is barbaric"2 automatically comes to one's mind. Naomi Mandel in her

\footnotetext{
* This work was supported by the Polish National Science Centre (Narodowe Centrum Nauki) under Grant UMO-2017/27/B/HS2/00111.

${ }^{1}$ Marianne Hirsch, Family Frames. Photography Narrative and Postmemory (Cambridge and London: Harvard University Press, 2002), 22.

${ }^{2}$ Theodore Adorno, Prisms, transl. Samuel and Sherry Weber (Cambridge: The MIT Press, 1983), 34 .
} 
essay on Adorno's philosophy suggested a few remarks of similar nature discussed by various scholars and thinkers, such as Steiner's "The world of Auschwitz lies outside speech as it lies outside reason," and Wiesel's "Auschwitz negates all systems...," Throughout the last seventy years, these declarations have coincided and collided with the already well established literary tradition of writing about the Holocaust experience by the first and second (as well as third) generation survivors. This phenomenon represents what Agamben ${ }^{4}$ exemplifies as a claim that neither poetry nor music can contribute to salvaging the impossible testimony; on the contrary, this testimony can found the possibility of poetry. ${ }^{5}$ Similarly, rabbi Pecaric calls it "Speaking the Silence" 6 and Mandel defines as "Against the rhetoric of the Unspeakable." Also, Hirsch repeatedly refers to the children of survivors as marked by postmemory understood by her as "a diasporic aesthetics of temporal and spatial exile that needs simultaneously to (re)build and to mourn." ${ }^{8}$ As a result, second generation texts, which are discussed in the subsequent sections of this article, can be seen as postmemorial as they restore the past as well as try to probe the chances of life beyond the Holocaust.

With this grand philosophical and literary tradition in mind, it is interesting to trace the postmemorial poetic voices in Australia and Canada in order to explore not only the variegated stylistics but first and foremost the poets' stance on the importance of remembering the trauma and commemorating the event central to their parents' lives. The comparative perspective also invites an outlook on how living in exile has shaped the perception of the past, Europe, the Holocaust legacy and postmemory and their expression in art. This paper addresses a poetic trilogy written by an Australian poet, writer and memoirist, Lily Brett, between 1986 and 1990 as well as selected volumes of poetry written by Anne Michaels, a Canadian writer and poet. Both Brett and Michaels are the second generation artists born outside Poland to their exiled Jewish parents and thus are seen as those whose "transnational identity inhabits the space of crossing or the location of dislocation" making it "transitive or navigational.",

\section{Lily Brett — an Australian Poet of/after Auschwitz}

Lily Brett was born in a Bavarian Feldafing DPs camp as a child of Holocaust survivors in 1946 and emigrated to Australia with her parents after two years. ${ }^{10}$ She is a Jewish-Polish Australian journalist, novelist, memoirist and poet. Kwapisz-Williams in her discussion on diasporic writers sees Brett as belonging to "a growing number of

\footnotetext{
${ }^{3}$ Naomi Mandel, "Rethinking 'After Auschwitz': Against a Rhetoric of the Unspeakable in Holocaust Writing," boundary 28, no. 2 (2001): 204.

${ }^{4}$ Giorgio Agamben, Co zostaje z Auschwitz. Archiwum i świadek (Homo Sacer III), transl. Sławomir Królak (Warszawa: Sic!, 2008), 36.

${ }^{5}$ Ibid. It is also essential to note that Agamben disagrees with using the term 'unspeakable' about the Auschwitz experience as it coincides for him with religious worship and adoration. This terminological dilemma is, however, beyond the scope of this research (cf. Agamben, Co zostaje z Auschwitz?, 31-32).

${ }^{6}$ Sacha Pecaric, "Niezdolność mówienia," last updated December 9, 2019, http://cdim.pl/ sacha-pecaric-niezdolnosc-mowienia, 1810.

${ }^{7}$ Mandel, "Rethinking," 203-228.

${ }^{8}$ Marianne Hirsch, Family Frames, 245.

${ }^{9}$ Catalina Botez, "Lost in Transculturation: Evicted Travellers in Lily Brett's Things Could Be Worse and Anne Michaels' Fugitive Pieces," Literature \& Aesthetics 20, no. 1 (2010): 92.

${ }^{10}$ Robert Eaglestone, "'Working through' and 'awkward poetics' in Second Generation Poetry: Lily Brett, Anne Michaels, Raymond Federman," Critical Survey 20, no. 2 (2008): 20.
} 
second generation writers, who developed their literary careers often struggling, as Mirelle Juchau observes, "for the right form and language to express an event that has preceded and sometimes dominated their childhood'."11 A child of Łodź ghetto and Auschwitz survivors, Lily Brett is an artist who has definitely striven to express her own take on the inherited post-Holocaust trauma. She is the author of a few novels, memoirs and an acclaimed poet. She has published several volumes of poetry and her writing career started with the publication of The Auschwitz Poems in 1986, later on followed by what finally became a trilogy: Poland and other Poems (1987) and After the War (1990). ${ }^{12}$ Eaglestone views her style as predominantly "naïve modernist" characterized by "descriptive lines of one or two words only, and a simple and clear vocabulary."13 The three part poetry collection is organized along a chronological sequence starting from the story of her parents' experiences in Auschwitz, their migration to Australia, to move in the second volume to Brett's depiction of her trip to Poland, whereas the third part of the trilogy comprises Brett's memories from her travel to Jerusalem as well as her attempt to come to terms with postmemorial mourning and to find a balance in her life.

The Auschwitz Poems is indeed a matter-of-factly narrated volume of poetry. Brett is economical with words and does not provide any elaborate and poetic visions of the camp existence. The main themes dominating this collection comprise the questions of survival and oscillation between existence and death as everyday experience of camp reality, physicality and transformation of bodies. Then, Brett chronologically moves to the moment of liberation and her parents' stay in the DP camp as well as their migration to Australia to finally discuss her own position vis-à-vis her parents' legacy of the Holocaust. The simplicity of language and harshness of images created in her poetry make Brett's texts brutal and devoid of emotions, and thus, compelling and paralyzing. What is also intriguing is the fact that she talks to her mother and father in the second person singular as if she had been there and observed them in the camp. It is visible throughout the whole volume and highlighted from the opening text titled "To the Left":

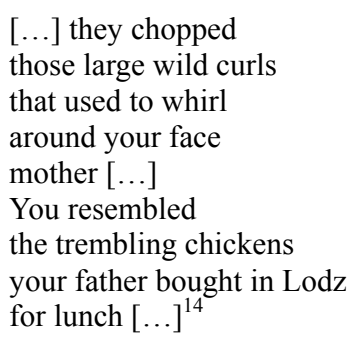

This conversational tone, present when Brett addresses her parents, also evokes the compelling necessity to tell her parents' story to them and to the others. It is either because the parents themselves cannot voice their trauma and have been suppressing or

${ }^{11}$ Katarzyna Kwapisz Williams, "Transnational Literary Cultures in Australia: Writers of Polish Descent," in The European Diaspora in Australia: An Interdisciplinary Perspective, eds. Bruno Mascitelli, Sonia Mycak, and Gerardo Papalia (Newcastle upon Tyne: Cambridge Scholars Publishing, 2016), 126.

${ }^{12}$ The Auschwitz Poems was awarded Victorian Premier's Literary Awards: C. J. Dennis Prize for Poetry in 1987 and Poland won the Mattara Poetry Prize in 1986 (nowadays this prize is called Newcastle Poetry Prize and is an annual Australian poetry prize awarded since 1980).

${ }^{13}$ Eaglestone. "“Working through'," 20.

${ }^{14}$ Lily Brett, Auschwitz Poems (Wien and Frankfurt am Main: Suhrkamp, [1986] 2004), 161. 
even repressing the past. It is thus the second generation's task to make the story heard. If telling the traumatic past has a therapeutic aspect, and the survivors cannot undertake the burden themselves, Brett seems to believe it is her obligation to break the silence and, from the perspective of Australian distance and safety, reclaim and retell the past.

The Auschwitz Poems also includes poems devoted to all shades of camp reality. A large portion of this poetry clearly exposes the Nazi's crimes. It is visible in the texts devoted to Dr. Mengele's experiments, regular camp selections to send people either to death or to labor, or a selection of poems devoted to the terrifying fate of children in the camp ("Children I"):

$$
\begin{aligned}
& {[\ldots]} \\
& \text { to kill } \\
& \text { the children } \\
& \text { it was easy } \\
& \text { they were } \\
& \text { flung in the air } \\
& \text { for target } \\
& \text { practice. }
\end{aligned}
$$

Furthermore, there are poems exploring the topic of starvation in the camps, texts presenting situation of those who were richer and had some possessions, and thus, were involved in camp trade as well as poems discussing the camp suicides. Her themes cover a whole range of barbaric behavior as well as an unspeakable amount of suffering. Brett here refrains from pathos and elevated language. On the contrary, she never abandons her withdrawn, down to earth, almost unpoetic narration, formed in the imagist and turpist style. In the poems such as "Canada" and "What Was Left" depicting the Canada section ${ }^{16}$ of the camp, which

$$
\begin{aligned}
& \text { swallowed } \\
& \text { its loot } \\
& \text { from } \\
& \text { queues } \\
& \text { of human cargo, }{ }^{17}
\end{aligned}
$$

Brett accentuates her attachment to factual data even more:

$$
\begin{aligned}
& \text { When } \\
& \text { The } \\
& \text { rest of the world } \\
& \text { woke up } \\
& \text { they } \\
& \text { found } \\
& \text { in what } \\
& \text { was left } \\
& \text { of } \\
& \text { Canada } \\
& \text { the six barracks } \\
& \text { that hadn't }
\end{aligned}
$$

${ }^{15}$ Ibid.

${ }^{16}$ Canada, or Kanada, officially called Effektenlager, was a section of the camp in Auschwitz, in which all the valuable possessions of those who had been sent to gas chambers were stored (cf. W. George Lovell. "Kanada at Auschwitz," The Canadian Jewish News, Accessed July 20, 2020, https://www.cjnews.com/featured/jewish-learning/kanada-at-auschwitz).

${ }^{17}$ Brett, Auschwitz Poems, 167. 


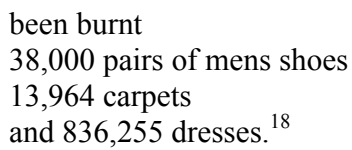

Calling her mother "a graduate" who

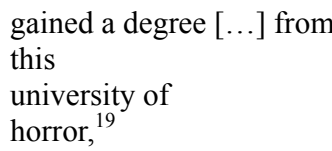

in a poem of the same title, is a bitter conclusion of the Holocaust experience the survivors gain. Being straightforward and detached gives Brett a unique perspective of a postmemorial witness who is there to give testimony but also somebody who is infected with the inability to forget. Liberation does not really mean that afterwards life becomes easy and fortunate all the time. The final days in the camp, depicted in a poem "The Last Day," are remembered as worse than anything, when

$$
\begin{aligned}
& \text { a man } \\
& \text { cooked } \\
& \text { his } \\
& \text { friend's } \\
& \text { liver }^{20}
\end{aligned}
$$

marking the survivors with the everlasting token of death. These memories cannot be easily shed off, which appears to be desired by their new homeland.

Emigration is for Brett's family the only chance to flee Europe identified with the destruction and mass killing forever. The poet realizes that the beginnings in the new environment were difficult for her parents as they had to deal "with Aftermath trauma to which the first-generation survivors are severely exposed in the wake of genocide, in the labour/displaced persons' camps and post-war migration, as well as the difficulties encountered by their offspring (i.e., the second-generation survivors) when dealing with parental distress and their own confused sense of self in the transcultural environment." 21 Thus, Brett devotes a selection of her poems to the variegated experiences of trauma as experienced alongside "transmigration.",22

In "Arriving in Australia" she, for example, writes:

When
you
arrived
you
imagined
you'd
be
treated
like
kings
welcomed

0.
"Lost in Transculturation," 94.




with
open
arms
looked
at
lovingly [...]
what
greeted
you
were
anxious
faces
they
said
we
know
you've
been
through
a lot
but
it's
best
not
to
disturb
yourself
with
those
thoughts
it
took
you
forty
years
to
try
to
talk
about
it.

As it can be seen, emigration offers a change of place but not necessarily provides comfort and soothing atmosphere. On the contrary, the more beautiful the landscape is, the more disturbing nightmares appear. In a few poems describing the family's early years in Australia, Brett contrasts allure and contentment with depressing memories lurking in the shadows. She describes Australia in "Three Days Later" as

$$
\begin{aligned}
& \text { this } \\
& \text { blue } \\
& \text { cloudless } \\
& \text { country, }
\end{aligned}
$$

\footnotetext{
${ }^{23}$ Brett, Auschwitz Poems, 172.
} 
and shows the aforementioned opposition in "Our House":

In
our
shiny
square house
with
rose bushes
and
fig trees $[\ldots]$
on anniversaries
of bad memories
they wept
and wailed $\left[\ldots . .{ }^{25}\right.$

In her poetry, when referring to the Bretts' life in exile, she mentions all the positive aspects of living in this beautiful and rich country such as advanced technology, weather, and mostly the abundance of food. Yet, her texts repeatedly reveal rifts of unbelonging and post-Holocaust syndrome of impossibility of dealing with everyday reality. Although, "everything looked normal," ${ }^{26}$ the pain was even shared by the floor, cupboards, and "banished sadness" ${ }^{\text {"27 }}$ permeated the house. For eleven poems referring directly to their emigration to Australia and initial period in the new homeland, there are five poems dedicated to food and eating. In "For Breakfast," Brett mentions what food the family ate for dinners and breakfasts, the way her parents

$$
\begin{aligned}
& \text { squeezed } \\
& \text { dozens } \\
& \text { of } \\
& \text { oranges }^{28}
\end{aligned}
$$

to prove they are safe and live in affluence yet simultaneously revealing past traumas and food shortages that may never be forgotten.

Typically of the second generation, Brett is also a witness of her parents' struggle to quench memories and not to infect their children with the traumatic past. In the finale of the first volume of poetry, chronicling their early years in Australia, she notices her father's compulsive eating and the shadow of the Holocaust experience in her mother's eyes. It is recapitulated in the poem titled "Father":

I
held
my breath
and
knew
you
were
defying
death
each
night

\footnotetext{
${ }^{24}$ Ibid.

${ }^{25}$ Ibid.

${ }^{26} \mathrm{Ibid}, 173$.

${ }^{27}$ Ibid.

${ }^{28}$ Ibid, 174.
} 


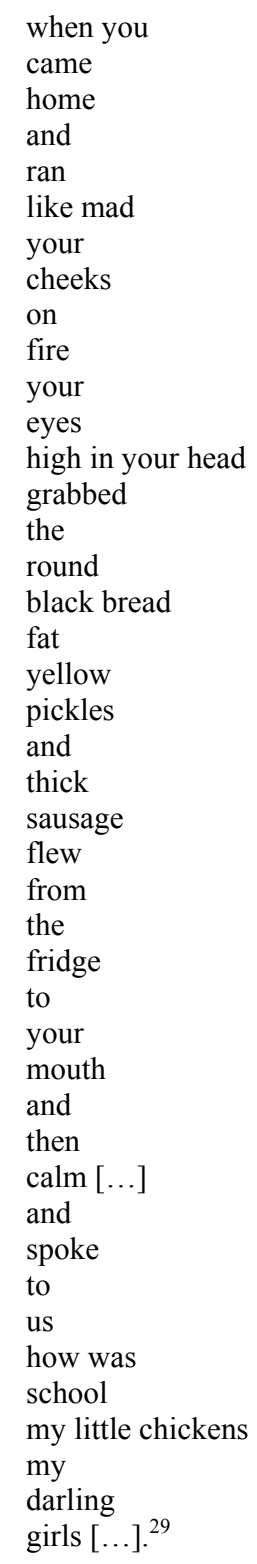

It is not only food that becomes the mirror of certain disorders and dysfunctions. As a daughter, Brett witnesses her mother's absence, even, when she scrubs the floors "with more ferocity,"30 she was more concerned with the dead, with the traumatic memories than with the current situation at home. Therefore, in the same volume, in one of the closing poems "Be Yourself," Brett addresses her mother:

\footnotetext{
${ }^{29}$ Ibid, 174.

${ }^{30} \mathrm{Ibid}, 173$.
} 


you'd sit by yourself
somewhere else
you
couldn't
touch me
mother
you
had to
hold yourself

and in "I Wear Your Face," which, should be quoted in full length, she adds:

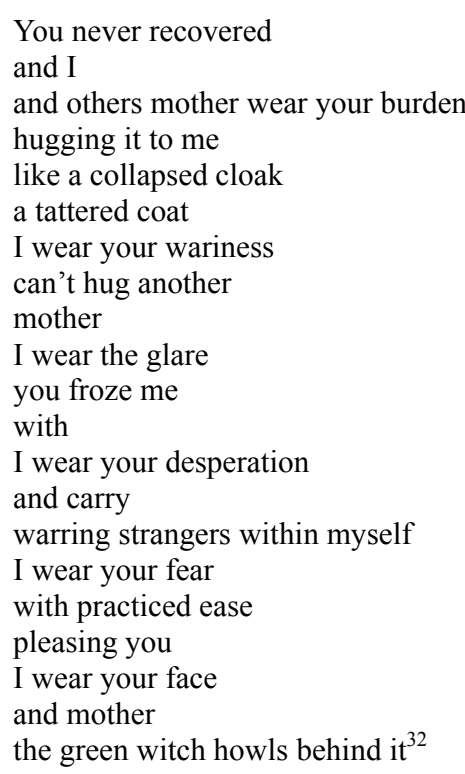

Her observations evoked the unexpressed memories of hunger of the camps on the one hand and, as in "I Wear Your Face," the impossibility of forgetting and shedding the Holocaust past off, on the other. Although Brett acknowledged the soothing potential of Australia, moving there did not erase memories and heal the traumas.

These poems also illustrate the ways in which Lily Brett was passed on the burden of the Holocaust. Never expressed straightforwardly by her parents, the haunting presence of ghosts of the past has become her inheritance and she voices the existence of these specters in writing. According to Hirsch, the second "generation's practice of mourning is as determinative as it is interminable and ultimately impossible, ${ }^{, 33}$ and thus art frequently becomes the only outlet for the cumulated postmemory. For Brett, as it is declared in "Today I," it is the "panic phantom" and
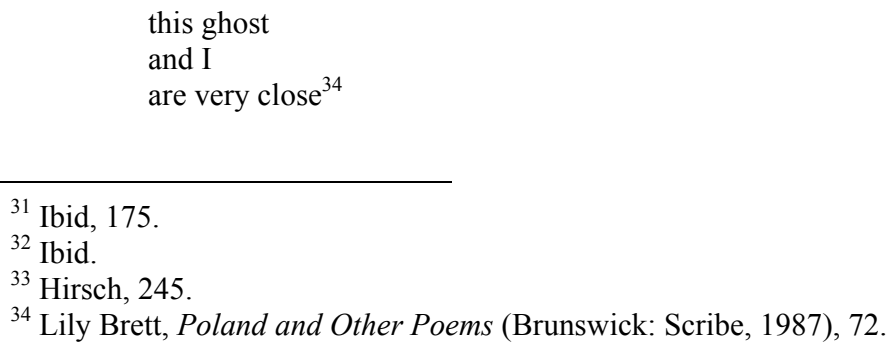
It is not clearly stated if the details of the camp life, which Brett includes in her poetry, are imagined, or excavated by herself from other Holocaust testimonies. As it has already been mentioned, Brett in each of the poems addresses her parents by 'you' as if it were the poet herself who told their story to them. It is, thus, the second generation artist and child of survivors who tells her parents' story to them and to the world. She expresses the unspeakable because they probably cannot deliver the story themselves. Such an impossibility of talking about the war experiences is a typical hindrance for Holocaust survivors. Rabbi Sacha Pecaric from the Center for Dialogue and Prayer in Auschwitz explained in 1999 different meanings of the word 'silence.' He differentiated between the two semantic scopes: there is silence, sztika, which means being quiet, not speaking and there is silence, dumija, when a human being is speechless and is unable to speak due to the traumatic memories. ${ }^{35}$ A similar phenomenon is observed by Cathy Caruth upon her experience as an interviewer and scholar employed in gathering recordings of the Holocaust survivors at the Fortunoff Video Archive. She claims that "the imperative to tell the story of the Holocaust is inhabited by the impossibility of telling, and therefore, silence about the truth commonly prevails." ${ }^{, 36}$ The decision not to talk about the past is not an innocent one. These who are silent "become victims of a distorted memory." 37 This memory influences their own lives as they live in the constant shadow of the evil from the past as well as their children's.

Brett,

$$
\begin{aligned}
& \text { a } \\
& \text { child } \\
& \text { of } \\
& \text { ash, }
\end{aligned}
$$

as she calls herself in "A Child," gradually learns how to speak the unspeakable through her poetry and prose instead of her parents. It is the second generation survivor who takes over the task of telling from their forebears.

In Poland and other poems (1987), she discusses her travel around Poland, visits "this grim city" 39 of Łódź, and displays the symptoms typical of the second generation such as anxiety, anger, sadness mixed with her own consciousness of being an exiled child of postmemory. Starting with the first poem in the collection entitled "The Immigration Man" in which she feels she "might faint" about her nationality at the airport and she asks her mother:

$$
\begin{aligned}
& \text { could he be } \\
& \text { one of the } \\
& \text { Poles } \\
& \text { who pointed you out } \\
& \text { mother } \\
& \text { who called back the Nazis }{ }^{41} \text {. }
\end{aligned}
$$

${ }^{35}$ Pecaric, "Niezdolność."

36 Cathy Caruth, Trauma. Explorations in Memory (Baltimore: The Johns Hopkins University Press, 1995), 64.

${ }^{37}$ Ibid.

${ }^{38}$ Brett, Poland, 63.

${ }^{39}$ Ibid, 23.

${ }^{40}$ Ibid, 5 .

${ }^{41}$ Ibid. 
Similarly, when wandering in Łódź, she unexpectedly cannot disburden the memory which is not hers but her parents.' She, thus somatically feels, what they felt many years earlier and depicts these sensations in "At Eight O'clock":

another
policeman
marches past me
on
Kilinskiego
street
and
I
freeze
I
cannot
breathe
I
have
you here
mother.

Brett effuses the inherited trauma in her poetry, similarly to Hoffman who says "We grew up not with the Holocaust, but with its aftermath; or rather, with that aftermath as it was lived in our parents' psyches. Our first consciousness of the Shoah was transmitted to us through means that were bodily, palpable, densely affective." Moreover, in this clearly autobiographical poetry, Brett goes even further claiming a total unification with her mother, or her mother's experience. Despite the fact that Lily Brett emigrated to Australia as a very small child, she never acquired the status of an Australian solely. Her transnational and transcultural self-identification makes her remain on the fringes, between two worlds, two legacies, navigating through displacement and never reaching the moment of closure. In "I Have Never Known," she straightforwardly admits:

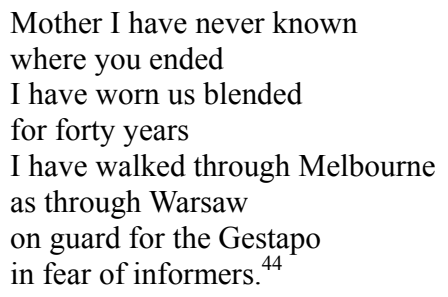

In one of the most important poems in the collection "Poland," she sums up her attitude to Poland as well as analyzes her relationship to her mother who cannot understand Brett's decision to visit Poland:

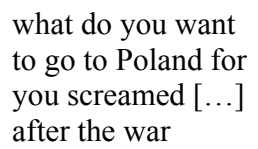

${ }^{42}$ Ibid, 43.

${ }^{43}$ Eva Hoffman, After Such Knowledge. A Meditation on the Aftermath of the Holocaust (London: Vintage, 2005), 33.

${ }^{44}$ Brett, Poland, 133. 


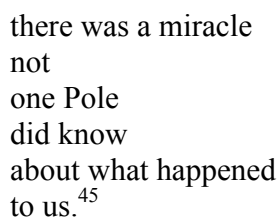

In the final volume of Brett's poetic trilogy, she fully confides her postmemorial status to her readers in the poem "Killing Me" where she

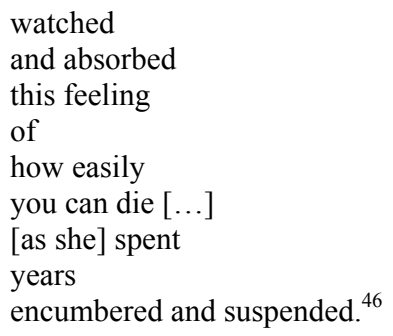

It is apparent that being burdened with such feelings and memories is not a matter of mature years when understanding of what the Holocaust was comes. These poems question the possibility of recuperative potential of writing and telling the stories of trauma. As the remnants of Auschwitz experience in the second generation survivors are traced back into childhood, the trilogy does not seem to offer a suggestion that you can talk yourself out of the predicament of remembering. Brett's obsession to go back to her own premature years to retrace the beginnings of infection, does not reveal the way out of the trap. When Brett revisits her childhood, she notices the early symptoms of this kind of mental weight. In a poem "People Weeping" about her infancy she says:

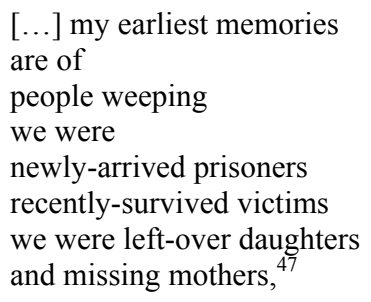

and she continues in "When I Began":

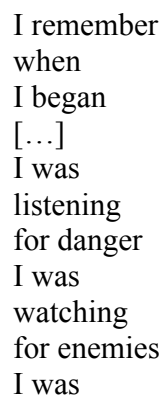

\footnotetext{
${ }^{45}$ Ibid, 139-140.

${ }^{46}$ Lily Brett, After the War (Melbourne: Melbourne University Press, 1990), 80.

${ }^{47}$ Ibid, 70.
} 


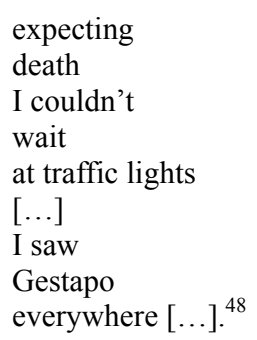

This final volume in the trilogy, significantly entitled After the War, also seeks answers to a question whether a poet can be liberated from the ghostly presence of the past, from the fear and tremble, even though she lives in a free and peaceful Australia. Quite obviously, there is not one response to the quandary. It is a challenge to quench the postmemory as it somehow entails forgetting about one's parents' experiences. In "Leaving You" she claims:

It has taken me
a long time to know
that it was your war
not mine
that I wasn't
in Auschwitz
myself
that I have never
seen
the Lodz Ghetto. ${ }^{49}$

Even though this poem may suggest a possibility of liberation, she realizes the chance of forgetfulness is a mirage. If one progresses through the collection chronologically as the pages indicate, after two poems Brett announces the vanity of such thinking saying: "I thought this fear would leave me..." and after the next two, she confirms in a poem titled "Old Enough":

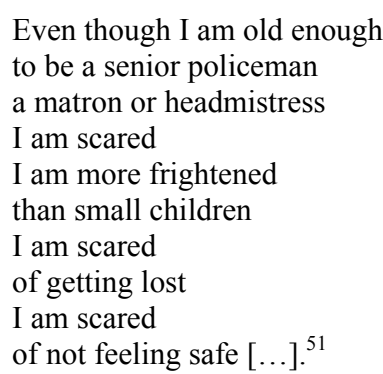

Brett's search for safety and self-identity as a second generation Holocaust survivor cannot be freed from the burden of the past unintentionally inflicted upon her by her parents. Her poetic trilogy is therefore clearly located within the postmemorial turn which addresses the aftermath of the Shoah and the responses of the second generation to the unspeakable atrocities their parents witnessed. Brett's seemingly detached and

\footnotetext{
${ }^{48}$ Ibid, 87.

${ }^{49}$ Ibid, 91

${ }^{50}$ Ibid, 95 .

${ }^{51}$ Ibid, 99.
} 
clear tone makes her voice the burden of the generations that have come 'After Auschwitz. " The "generational distance," for those born in its aftermath allowing them to write their own postmemory of the Holocaust.

\section{Anne Michaels — From an Elegy to Meditation}

Among Anne Michaels' poetic oeuvre two most recent volumes have to be mentioned in the context of postmemorial writing: Correspondences (2013) and All We Saw (2017). Correspondences is a highly experimental project created in cooperation with a visual artist, Bernice Eisenstein. This collection of poetry, illustrations and quotes is described as an elegy to Michaels' father. ${ }^{54}$ Being immensely intertextual and hybrid, the book in its harmonic form evokes the ideas of continual reading and Bakhtinian heteroglossia. One part of the volume consists of Eisenstein's drawings of famous figures rooted in different ways in the Holocaust experience and accompanied by compact quotations from each person portrayed there. On the back of those pages, there is a book-long elegiac poem commemorating Isaiah Michaels. ${ }^{55}$

Among the twenty six portrayals accompanied by quotations there are many which directly refer to the question of memory. Moreover, the fact that Michaels and Eisenstein introduce them would prove that the second generation artists still need to confront themselves with the inherited past. The people included in the text are, among others, Anna Akhmatova, Albert Einstein, W.H. Sebald, Paul Celan, Albert Camus, Rose Ausländer, Franz Kafka, Nelly Sachs, Etty Hillesum, Isaiah Michaels or Bruno Schultz. Bearing in mind that Michaels and Eisenstein are both children of Holocaust survivors born after the war (Michaels was born in 1958 and Eisenstein in 1949, both in Toronto), their texts undoubtedly can be located in the context of postmemory. Therefore, in their joint project, they tackle the issue of how they have been formed through the Holocaust memory handed down from the generation of their parents. Since Hirsch sees postmemory as "obsessive and relentless," "as full and as empty," this discursive and dynamic phenomenon opens up Michaels's perspective onto her

\footnotetext{
${ }^{52}$ On the rhetoric of the unspeakable, see Mandel, "Rethinking," 203-228.

${ }^{53}$ Hirsch, Family frames, 22.

${ }^{54}$ Michaels has distinguished herself as both a poet and a novelist. She is known internationally for the beauty and precision of her language and the depth of her philosophical themes. She is the author of two worldwide bestsellers: Fugitive Pieces (1997) and The Winter Vault (2008), numerous volumes of poetry and other texts of various genres. She is considered a Canadian writer and poet in many critical sources (cf. Rachel Falconer, Hell in Contemporary Literature (Edinburgh: Edinburgh University Press, 2007), 105 and Eaglestone, The Holocaust and the Postmodern (Oxford: Oxford University Press, 2008), 78, 79). Some authors refer to her origins mentioning the fact the she was "born in Toronto of Jewish parents, her father a Russian immigrant" (Eugene Benson and William Toye, The Oxford Companion to Canadian Literature. (Toronto and Oxford and New York: Oxford University Press, 1997), 753) but she is very rarely associated with Polish-Canadian or Russian-Canadian diasporas. In a short biographical note concerning her father Isaiah Michaels included in Correspondences, Michaels wrote that he was born in Grodno, Poland (2013). This place is also echoed in an autobiographical poem "Lake of Two Rivers" in which she alluded to "our car from Grodno," "the River Neman" and "the train carrying my father across Poland" Anne Michaels, Miner's Pond, The Weight of Oranges. Skin Divers (London: Bloomsbury, 2000), 5-10.

${ }_{55}^{55}$ For detailed analyses of Correspondences see Drewniak (2018) and Drewniak (2019).

${ }^{56}$ Hirsch, Family frames, 22.
} 
father's biography, whose poetic rendition is intertwined with Eisenstein's meditation on post-Holocaust heritage included on the other side of the pages. Among a variety of pictures and fragmentary quotes it becomes discernibly clear that Michaels and Eisenstein try to cope with the inherited burden of the past. They also see it as a task that needs to be undertaken by anybody who reads and looks at the text and accompanying images. From Sebald's

And yet,

what would we be without memory $?^{57}$

through Ausländer's

$[\ldots]$ we sit around
the fragrant table
Amazed that we
are sitting here.
Layer
upon
layer,

to Etty Hillesum's conviction that those who die in the Holocaust are accompanied by those who remember:

$$
\begin{aligned}
& \text { Strangely I heard a stranger say: } \\
& \text { I am with you. }
\end{aligned}
$$

This communal history that becomes the post-WWII legacy therefore touches all the readers. Those who live now have to confront themselves with the pictures and short inscriptions from a variety of thinkers, writers and artists that have preceded them. Moreover, while the backs of the pages reveal the long elegiac poetry commemorating Michaels's father, the Holocaust victim and survivor, the corresponding drawings and citations become supplementary sources to understand Isaiah Michaels's position in reference to these figures. In this biographical and commemorative section, which would require a separate study, Michaels sees herself as an inheritor of her father's memories as well as a person living within the spectral presence of ghosts of the past. She writes:

$$
\begin{aligned}
& \text { the photos and the millions } \\
& \text { of indifferent eyes that have looked upon } \\
& \text { their shaven nakedness; } \\
& \text { the ghost life that lives itself } \\
& \text { beside us, the shadow of what happened } \\
& \text { and what didn't happen; } \\
& \text { If ever I lose } \\
& \text { my memory of you, walk beside me } \\
& \text { like a stag; like a bird heard, unseen. }
\end{aligned}
$$

The treatment of the Holocaust as a communal experience also shared by next generations is even multiplied when she evokes those who have not been born during the war like herself, but who are burdened with the ordeal:

57 Anne Michaels and Bernice Eisenstein, Correspondences (Toronto: McClelland \& Stewart, 2013), no page given.

$$
\begin{aligned}
& 58 \text { Ibid. } \\
& { }^{59} \text { Ibid. }
\end{aligned}
$$


even the unborn have a number, the same number not given to the mother and all those not worth counting. 60

Despite the physical and temporal distance of living in Canada in the twenty first century, both Michaels and Eisenstein do not see this gap as the one having a healing potential. On the contrary, the artists seem to feel the rift even more with each of deceased Holocaust survivor as of with each death the link and chance to find closure is lost. As children of Holocaust survivors, the authors seem to claim that consolation is not attainable as the event is perpetuated in the physical and mental sensations.

As a poet of loss, grieving and sharing "an intimacy with the dead," her 2017 collection of poetry All We Saw commemorates the death of her two close friends: Mark Strand and John Berger. Although not closely related to the Holocaust postmemory, they were of Jewish origins. Following Hirsch's idea, who believed that the notion of postmemory "may usefully describe other second-generation memories of cultural or collective traumatic events and experiences," $" 62$ she subscribes the loss of her Jewish friends to the operation and meditations of the same postmemorial mechanisms. Situating herself within a postgeneration, ${ }^{63}$ Michaels in All we Saw tries to grasp a larger perspective. Together with the death of her friends who, although not directly influenced by the Holocaust, lived through WWII, Michaels gradually realizes her generation is the only one that has to bear the burden of testimony. The first generation of survivors and those who saw "all" have died "because the Angel of Memory collects these souls from the ruins of history." ${ }^{, 64}$ In the text, Michaels comments on her conviction in a continuous conversation with the dead, which refers more broadly to her understanding of communal remembrance. When she writes:

$$
\begin{aligned}
& \text { words brought down } \\
& \text { by blows, struck } \\
& \text { to the depth } \\
& \text { of flesh, of } \\
& \text { haunting and naming } \\
& \text { [...] sung by a ghost, }{ }^{65}
\end{aligned}
$$

and:

[...] Somewhere, for the sake of his children, a man writes what he has seen

[...] Somewhere there is a man who has not forgotten anything and has written it down, ${ }^{66}$

she suggests she believes in a relationship with the dead and the importance of artistic commemoration.

${ }^{60}$ Ibid.

61 Shazia Hafiz Ramji. "All we Saw by Anne Michaels," 2017, last updated August 17, 2019, https:/quillandquire.com/review/all-we-saw/.

${ }^{62}$ Hirsch, Family frames, 22.

${ }^{63}$ Marianne Hirsch, The Generation of Postmemory (New York: Columbia University Press, 2012), 4

${ }^{64}$ John Berger and Anne Michaels, Railtracks (Berkeley: Counterpoint, 2012), 76.

${ }^{65}$ Anne Michaels. All We Saw (New York: Alfred A. Knopf, 2017), 9.

${ }^{66}$ Ibid, 21, 25. 
Such confidence in a close contact with the dead has been visible throughout Michaels' writing career. Both her prose and her poetry especially try to voice the legacy of the second generation. Her biographical elegiac poem included in Correspondences is just a proof of how she understands "communication with ghosts" to use Kafka's phrase from the collection. In All We Saw she affirms that "the dead can read" ${ }^{\prime 67}$ and, that is why in her 2013 elegy, she addresses her father:

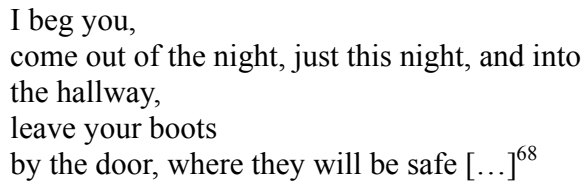

Writing this belated Kaddish for the dead, ${ }^{69}$ Michaels proves she is not only the treasurer of postmemory but also a witness of the first generation post-War torment ${ }^{70}$ and an unprecedented companion even after death. These themes and topics were suggested in her poetry quite early, already in the first collections. In The Weight of Oranges, published as early as 1986, she wrote:

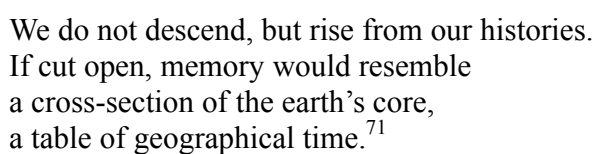

Being rooted in history and being burdened with its darkness have become a leitmotif in the aforementioned works. The observation of her father has formed her poetic style and made her recur to his gloom and strain, which becomes obsessive in Correspondences.

\section{Conclusion}

Born within twelve years, Lily Brett and Anne Michaels, though writing in two different stylistic modes, address comparable themes of postmemorial legacy the second generation Holocaust survivors and migrants carry in the aftermath of the Second World War. Brett, using the simple, detached language, and Michaels, through her long poetic 'narratives' both focus on bearing the burden of the inherited Holocaust experience and try to engage in delivering the unspeakable. If the Holocaust survivors frequently cannot speak and are paralyzed by dumija, there is a question who can speak and what language to use. In the case of the aforementioned poetry, one can state that it is the second generation poets who respond to Agamben's claim that "the poetic word is the one that is always situated in the position of a remnant and that can, therefore, bear witness." $" 72$ The comparative perspective also allows the readers to realize that the antipodean angle does not change the perception of being infected with the postmemorial experience. Despite idiosyncratic poetics typical of their personal

\footnotetext{
${ }^{67}$ Ibid, 57.

${ }^{68}$ Michaels and Eisenstein, Correspondences, no page given.

${ }^{69}$ Hirsch, Family frames, 247.

${ }^{70}$ In her Miner's Pond (from 1991), she also notes: "Sometimes I was afraid to touch him, / afraid my hand would go right through him. / [...] I prayed to the sky to lift out father's head, / to deliver him from memory." Michaels, Miner's Pond, 125.

${ }^{71}$ Anne Michaels, Miner's Pond, 9.

${ }^{72}$ Giorgio Agamben. Remnants of Auschwitz (New York: Zone Books, 1999), 161.
} 
testimonies, both Brett and Michaels respond to the same quandaries: how to embrace the rift of the unspeakable and how to give voice from the outside of the second generation. According to Mandel, "Emphasizing the unspeakability of the Holocaust is a common way in which the Holocaust writers make it possible to talk about the Holocaust without confronting the morally questionable implication of seeming to comprehend, to simplify, to judge." ${ }^{, 73}$ As a result, in their poetry, both Brett and Michaels refrain from the imperative to fully know and understand their parents' experiences, ${ }^{74}$ but rather observe, accompany, and shelter the first generation past in their postmemorial and exilic writing.

\section{BIBLIOGRAPHY}

Adorno, Theodore. Prisms. Transl. Samuel and Sherry Weber. Cambridge: The MIT Press, 1983. Agamben, Giorgio. Co zostaje z Auschwitz. Archiwum i świadek (Homo Sacer III). Transl. Sławomir Królak. Warszawa: Sic!, 2008.

Agamben, Giorgio. Remnants of Auschwitz. New York: Zone Books, 1999.

Benson, Eugene, and William Toye, eds. The Oxford Companion to Canadian Literature. Toronto and Oxford and New York: Oxford University Press, 1997.

Berger, John and Anne Michaels. Railtracks. Berkeley: Counterpoint, 2012.

Botez, Catalina. "Lost in Transculturation: Evicted Travellers in Lily Brett's Things Could Be Worse and Anne Michaels' Fugitive Pieces." Literature and Aesthetics 20, no. 1 (2010): 92-107.

Brett, Lily. Auschwitz Poems. Wien and Frankfurt am Main: Suhrkamp, [1986] 2004.

Brett, Lily. Poland and Other Poems. Brunswick: Scribe, 1987.

Brett, Lily. After the War. Melbourne: Melbourne University Press, 1990.

Caruth, Cathy. Trauma. Explorations in Memory. Baltimore: The Johns Hopkins University Press, 1995.

Drewniak, Dagmara. “'And yet, what would we be without memory?' Visualizing Memory in Two Canadian Graphic Texts.” Studia Anglica Posnaniensia 53 (2018): 5-24. doi: 10.2478/stap-2018-0001

Drewniak, Dagmara. “'It Is, After All, a Communication with Ghosts': Correspondences by Anne Michaels and Bernice Eisenstein as a Historical and Personal Elegy in the Aftermath of the Holocaust." In Aftermath. The Fall and Rise after the Event, eds. Robert Kusek, Beata Piątek, and Wojciech Szymański, 39-49. Kraków: Jagiellonian University Press, 2019.

Eaglestone, Robert. The Holocaust and the Postmodern. Oxford: Oxford University Press, 2008.

Eaglestone, Robert. “'Working through' and 'awkward poetics' in Second Generation Poetry: Lily Brett, Anne Michaels, Raymond Federman.” Critical Survey 20, no. 2 (2008): 18, 30.

Falconer, Robert. Hell in Contemporary Literature. Edinburgh: Edinburgh University Press, 2007.

Hafiz Ramji, Shazia. "All we Saw by Anne Michaels." Accessed August 17, 2019. https://quillandquire.com/review/all-we-saw/.

${ }^{73}$ Mandel, "Rethinking," 222.

74 The spectral presence of her relatives and friends informs Brett's and Michaels's "contemporary Aftermath literature" (cf. Botez, "Lost in Transculturation," 93) but also gives testimony to the rift of the vast unknown, which is also a part of their testimony. Therefore, theirs is the vision of the second generation twice translated. First by the distance of being children of Holocaust survivors and then by the fact of being born in exile and inhabiting a safe zone of Australian and Canadian multicultural society respectively. There is, however, another aspect of the unknown defined by Agamben. He claims that the second generation inherits the postmemory from the camp survivors so the privileged one to a certain extent. The full and complete witnesses died in Auschwitz so they were never able to give any testimony (cf. Agamben, Co zostaje z Auschwitz?, 32-35). 
Hirsch, Marianne. Family Frames. Photography Narrative and Postmemory. Cambridge and London: Harvard University Press, [1997] 2002.

Hoffman, Eva. After Such Knowledge. A Meditation on the Aftermath of the Holocaust. London: Vintage, [2004] 2005.

Kwapisz Williams, Katarzyna. "Transnational Literary Cultures in Australia: Writers of Polish Descent." In The European Diaspora in Australia: An Interdisciplinary Perspective, eds. Bruno Mascitelli, Sonia Mycak, and Gerardo Papalia, 114-135. Newcastle upon Tyne: Cambridge Scholars Publishing, 2016.

Lovell, W. George. "Kanada at Auschwitz." The Canadian Jewish News. Accessed July 20, 2020. https://www.cjnews.com/featured/jewish-learning/kanada-at-auschwitz.

Mandel, Naomi. "Rethinking 'After Auschwitz': Against a Rhetoric of the Unspeakable in Holocaust Writing." boundary 28, no. 2 (2001): 203-228.

Michaels, Anne. Miner's Pond. The Weight of Oranges. Skin Divers. London: Bloomsbury, 2000.

Michaels, Anne. All We Saw. New York: Alfred A. Knopf, 2017.

Michaels, Anne and Bernice Eisenstein. Correspondences. Toronto: McClelland \& Stewart, 2013.

Pecaric, Sacha. "Niezdolność mówienia." Accessed December 9, 2019. http://cdim.pl/sachapecaric-niezdolnosc-mowienia, 1810.

\section{POSTMEMORIAL EXPERIENCES - COMPARING AUSTRALIAN AND CANADIAN SECOND GENERATION MIGRANT POETRY ON THE BASIS OF SELECTED POETRY BY LILY BRETT AND ANNE MICHAELS}

This article aims to look at selected volumes of poetry by renown Australian and Canadian poets of the second generation such as Lily Brett and Anne Michaels and trace their attempts at dealing with the heritage of memory handed down by their parents. Locating their emigrant literary oeuvre within the context of Marianne Hirsh's idea of postmemory and the conviction that the post-Holocaust generations are "marked by memory" of their parents ([1997] 2002), Brett's and Michaels's poems can be viewed as written "against a rhetoric of the unspeakable" (Mandel 2001), a rhetoric which, according to Giorgio Agamben, lies foundations for poetry (1999). Both poets (whose literary output includes also novels) belong to the second generation of writers, born outside Poland after WWII, and they engage in considering the themes of postmemory, legacy of the Holocaust, and their personal take on the inherited trauma. Different in style and poetics, Brett's and Michaels's renditions of the traumatic past reveal striking similarities in evoking the topics of memory, languages, images of places and questions concerning the chances for and ways of healing despite the fact that the author live in such distant countries as Australia and Canada respectively. The article will, thus, explore the poets' stance on the importance of remembering the trauma and commemorating the event central to their parents' lives and mention the variegated stylistics which ranges from Brett's simple language to Michaels's extensive usage of metaphorical language.

KEY WORDS: Lily Brett, Anne Michaels, postmemory, postmemorial poetry, Holocaust poetry

\section{DOŚWIADCZENIA POSTPAMIECCI — PORÓWNANIE AUSTRALIJSKIEJ I KANADYJSKIEJ POEZJI EMIGRANTÓW DRUGIEGO POKOLENIA NA PODSTAWIE WYBRANYCH UTWORÓW LILY BRETT I ANNE MICHAELS}

Niniejszy artykuł podejmuje temat postpamięci i próby radzenia sobie z nią w poezji emigrantek drugiego pokolenia z Australii i Kanady: Lily Brett i Anne Michaels piszących i publikujących w języku angielskim. Wybrana poezja Brett i Michaels analizowana jest w kontekście teorii postpamięci w ujęciu Marianne Hirsch, a także traktowana jako sprzeciw wobec „retoryki niewysławialnego" (Mandel 2001). Ponadto, dyskusja nad świadectwem jakim może być poezja wyrasta z myśli Giorgio Agambena i jego przekonania, że „to świadectwo może ufundować 
możliwość poezji” (2008). Obie poetki, będące także autorkami powieści i innych tekstów z gatunku non-fiction, urodziły się poza Polską, po II wojnie światowej w rodzinach naznaczonych doświadczeniem Holokaustu. Angażują się one w swojej poezji w rozważania dotyczące postpamięci, dziedzictwa Holokaustu, a także w osobiste próby przepracowania odziedziczonej traumy. Mimo różnorodności stylu i poetyk, a także odmiennej perspektywy narzuconej poniekad przez dystans geograficzny, teksty Brett i Michaels wskazują na pewne podobieństwa w podejściu do pamięci, języka, obrazów czy pytań dotyczących radzenia sobie z traumą rodziców, która obecna jest w doświadczeniu drugiego pokolenia.

SŁOWA KLUCZOWE: Lily Brett, Anne Michaels, postpamięć, poezja postpamięci, poezja Holokaustu 